Ewa Tomaszewska

Uniwersytet Śląski

\title{
Teatr interaktywny. Między sztuką a edukacją
}

\section{Wprowadzenie}

Sztuka dla dziecka to przestrzeń istnienia wspólnoty wrażliwych, twórczych ludzi - dorosłych i dzieci. Jednocześnie spotkanie ze sztuką należy traktować jako okazję i czas do głębszych przemyśleń zarówno odbiorcy jak i twórcy. Ciekawym spostrzeżeniem dzieli się Krystyna Miłobędzka, gdy mówi, że pierwszym impulsem do napisania sztuki Ojczyzna było dla niej pytanie małego synka: „Mamo, a co to jest ojczyzna?”. To pytanie nagle zmusiło ją do zastanowienia się nad tym pojęciem, które tylko pozornie wydawało się proste i oczywiste. Aby zatem odpowiedzieć synowi, Miłobędzka najpierw musiała odpowiedzieć sobie ${ }^{1}$. Sztuka stała się zapisem jej własnych przemyśleń na temat ojczyzny. Wynika z tego, że artysta, który tworzy dla dzieci, powinien z całą powagą mówić o sprawach, które nurtują jego samego i o których sądzi, że należy je dzieciom przedstawić. Jego artystyczna wypowiedź jest więc wypowiedzią człowieka dorosłego, z doświadczeniem, i spływa do dziecka niejako „z góry”. To zupełnie co innego niż wypowiedź dziecka realizowana w materii sztuki (w rysunku, tańcu, próbach literackich czy w teatrze amatorskim). Tu stawia się przede wszystkim na ekspresję własną uczestników artystycznych działań, która wypływa $\mathrm{z}$ jednej strony z obserwacji otaczającego świata, z drugiej - z doświadczeń własnych młodego, nieprofesjonalnego twórcy. To świat widziany z perspektywy dziecka. Wypowiedzi artystyczne dzieci realizowane w ramach tzw. edukacji estetycznej oraz twórczość profesjonalnych, dorosłych artystów adresowana do młodych odbiorców są niejako równoległe i dopełniają się wzajemnie.

Sztuka profesjonalna i sztuka amatorska przecinają się jednak, tworząc wspólną przestrzeń, którą stanowią nie tylko tworzywo i metoda artystycz-

${ }^{1}$ Wolne miejsce dla wyobraźni, wywiad z Krystyną Miłobędzką przeprowadzony przez Ewę Tomaszewską, „Filia” 1995/1996, nr 25, s. 7-9. 
nej kreacji, ale także oddziaływanie edukacyjne. Edukację należy tu rozumieć jako permanentny proces uczenia się i rozwoju człowieka trwający od narodzin do śmierci. Dydaktyka szkolna jest zaledwie niewielką, choć z pewnością znaczącą, częścią tego procesu i nie o tej formie oddziaływań będzie dalej mowa.

Teatr to jedna z najstarszych sztuk, a jej niezwykła zaleta polega na konieczności żywego kontaktu twórców $\mathrm{z}$ odbiorcami. W przeciwieństwie do wszechobecnych seriali i for internetowych teatr jest bezpośrednim spotkaniem człowieka z człowiekiem. Posługuje się językiem znaku i metafory, przez co dociera do najgłębszych sfer naszej osobowości, poruszając delikatne struny ludzkiej wrażliwości. Wskutek jednak życia w ciągłej gonitwie, w nadmiarze kolorowych reklam i pustce sloganów, nasza wrażliwość na otaczający świat zostaje stępiona. Otoczeni szybko zmieniającymi się obrazami wideoklipów, głośną muzyką, rytmami wprawiającymi w trans, krzykliwymi okładkami gazet nie mamy już czasu na refleksję i dajemy się ponieść z prądem mód i trendów, których najczęściej nawet nie rozumiemy.

Jesteśmy poddawani stałej manipulacji, której szczególnie łatwo ulegają dzieci i młodzież. A przecież czas dojrzewania to czas, kiedy człowiek formuje siebie, swój system wartości, poglądy, kiedy wytycza sobie życiowe cele. Dlatego sytuacja dzieci i młodzieży jest szczególne trudna. Nie można pozostawić ich samych, nie można jednak również siłą wymuszać postaw, które pasują dorosłym. Nowe pokolenia nie tylko przenoszą w przyszłość dziedzictwo poprzedników i utrwalają je w pamięci zbiorowej, ale także kontestują stary ład, dzięki czemu możliwe są zmiany, a te stanowią warunek rozwoju. Młodemu pokoleniu należy zatem stworzyć warunki do poszukiwania własnych dróg, które jednak powinny wychodzić z doświadczeń i przemyśleń już istniejących. To baza, z której można korzystać bądź nie, ale, co ważne, takie decyzje powinny być świadomym wyborem.

Od ponad dziesięciu lat w ramach działalności Zakładu Edukacji Kulturalnej Instytutu Nauk o Edukacji na Uniwersytecie Śląskim w Katowicach Wydział Etnologii i Nauk o Edukacji w Cieszynie prowadzę badania dotyczące teatru dla dzieci i młodzieży, który traktuję jako platformę przenikania idei oraz formowania się opinii. Celem, jaki sobie stawiam, jest poszukiwanie takiej formy teatru dla dzieci i młodzieży, który obok funkcji estetycznej spełniałby także funkcję edukacyjną rozumianą jako wspomaganie indywidualnego i wszechstronnego rozwoju każdego uczestnika naszych działań. Chodzi zarówno o rozwijanie wyobraźni, jak i intelektualnego myślenia. 
Realizację tych zadań prowadzę wraz ze studentami specjalności animacja społeczno-kulturalna (ASK) oraz dzięki finansowemu i organizacyjnemu wsparciu Fundacji Animacji Społeczno-Kulturalnej.

Nasze działania są uwarunkowane wiekiem odbiorcy - inne możliwości intelektualne, potrzeby i doświadczenia mają dzieci małe, inne - młodzież. Dlatego niezwykle ważne jest znalezienie różnych form języka teatralnego, który będzie przemawiał do widzów w różnym wieku i jednocześnie budził ich z egzystencjalnej drzemki. Stąd już tylko krok do tworzenia wewnętrznego świata, który jest podstawą własnej niezależności. Chodzi o to, aby ten język łączył atrakcyjność przekazu z atrakcyjnością formy, ale jednocześnie budował w odbiorcach przestrzeń dla ich własnych przemyśleń. Poszukujemy zatem nowej formy teatru wspartej interakcjami z publicznością, które włączają ją do procesu kreacji. Stąd robocza nazwa: „teatr interaktywny”, który rozumiemy jako formę teatralnych działań włączających widzów w akcję w znacznie większym stopniu niż czyni się to w tradycyjnym teatrze.

\section{Działania teatralne inspirowane pomysłami Jana Dormana}

Proponuję szybki przegląd naszych realizacji teatralnych, które miały cechy eksperymentów artystycznych. Pomysły zaczerpnęliśmy z pism i doświadczeń Jana Dormana, które jednak dostosowane były do naszych możliwości i do naszych czasów.

1. Kaczka i Hamlet, 2003 (eksperyment adresowany do dzieci w wieku 5-6 lat) - dwa rekwizyty teatralne, dwie kaczki, pozostawały w przedszkolach przez 2 tygodnie, potem dzieci przyszły na spektakl, w którym kaczki z przedszkoli były bohaterkami przedstawienia ${ }^{2}$.

Założenia eksperymentu:

1. Czy dzieci z przedszkoli badanych lepiej odbiorą przedstawienie niż dzieci z przedszkoli kontrolnych? Czy i w jaki sposób wcześniejsze oddziaływanie na odbiorcę sztuki teatralnej wpływa na recepcję przedstawienia?

2. Czy dzieci z epoki mediów są w stanie zaprzyjaźnić się z teatralnymi kaczkami, czy rekwizyty te mogą stać się dla dzieci ważne i atrakcyjne?

${ }^{2}$ Szczegółowe informacje na temat całego eksperymentu znaleźć można w artykule E. Tomaszewskiej Kaczka i Hamlet. Eksperyment teatralno-pedagogiczny, [w:] M. Knapik, W. A. Sacher, (red.), Sztuka w edukacji i terapii, Kraków 2004, s. 82-95; także Kaczka i Hamlet. Kilka uwag z eksperymentu, [w:] K. Krasoń, B. Mazepa-Domagała (red.), Ekspresja twórcza dziecka, Katowice 2004, s. 231-238. 
Obserwacje:

1. Dzieci z wszystkich przedszkoli (eksperymentalnych i kontrolnych) dobrze odebrały przedstawienie.

2. Dzieci z przedszkoli eksperymentalnych w sposób bardziej otwarty, spontaniczny, bez zahamowań reagowały na przedstawieniu w przeciwieństwie do dzieci z przedszkoli kontrolnych, które wyraźnie hamowały swoje emocje i spontaniczne reakcje.

3. Dzieci z przedszkoli eksperymentalnych bardzo dobrze rozumiały sytuację teatralną, tzn. fakt, że zarówno aktorzy jak i kaczki przyjmują na siebie role teatralne niezależne od pozateatralnych uwarunkowań.

4. Nauczyciele w znacznie mniejszym stopniu rozumieli istotę działań scenicznych niż dzieci.

Wnioski:

1. Wcześniejsza stymulacja w nieznacznym stopniu wpływa na rozumienie przedstawienia.

2. Wcześniejsza stymulacja wyraźnie wpływa na sposób emocjonalnej reakcji dzieci na przedstawieniu.

3. Dzieci doskonale rozumieją sytuację teatralną.

4. Dzieci bez problemu są w stanie zaprzyjaźnić się z teatralną lalką, która staje się dla nich atrakcyjnym partnerem w zabawie. Należy dodać, że zachowanie dzieci z 2003 roku było bardzo podobne do zachowań dzieci z roku 1968.

2. Młynek do kawy, 2005 (eksperyment adresowany do dzieci w wieku 12-14 lat) - spektakl oparty na poetyckim opowiadaniu K. I. Gałczyńskiego i scenariuszu Jana Dormana miał być próbą zbudowania przedstawienia adresowanego do grupy wiekowej odbiorców sztuki znajdującej się pomiędzy kategoriami: „dzieci” i „młodzież”. Tę grupę stanowią dzieci w trudnym, przejściowym wieku dorastania i prawdopodobnie $\mathrm{z}$ tego powodu $\mathrm{z}$ reguły pomijaną jako odrębna grupa odbiorców posiadająca własne, specyficzne potrzeby i uwarunkowania wychowawcze i estetyczne ${ }^{3}$.

Założenia eksperymentu:

1. Pierwsze założenie polegało na złożeniu przedstawienia z kilku dopełniających się elementów: plakatu, aranżacji foyer teatralnego, programu i właściwego widowiska - celem działań było zaktywizowanie

\footnotetext{
${ }^{3}$ Szczegółowe informacje na temat całego eksperymentu znaleźć można w artykule E. Tomaszewskiej Młynek do kawy, czyli teatr dla dzieci starszych, [w:] K. Krasoń, B. Mazepa-Domagała (red.), W kręgu sztuki i ekspresji dziecka. Rozważania inspirujace, Mysłowice 2006, s. 238-244.
} 
dziecięcego widza i próba mobilizacji do stworzenia w wyobraźni własnej wizji spektaklu.

2. Zbudowanie przedstawienia przy wykorzystaniu antyiluzyjnych środków wyrazu bazujących na symbolu i metaforze, a także wywodzących się z form zabaw dziecięcych - chodziło o wciągnięcie widza do intelektualnej gry, pobudzenie do własnych interpretacji i przemyśleń. Obserwacje:

1. Nie byliśmy w stanie precyzyjnie ocenić, w jakim stopniu dzieci połączyły w całość wszystkie elementy eksperymentu (plakat, aranżacja foyer, program i spektakl). Prawdopodobnie nie znaleźliśmy odpowiedniego klucza do zbadania tego aspektu naszego eksperymentu. Niemniej pewne elementy wskazują, że takiej syntezy nie było: a) plakat wisiał w szkole zbyt krótko i w ogólnodostępnym miejscu, a nie w klasie; być może wiele $\mathrm{z}$ dzieci w ogóle tego plakatu nie widziało; b) dzieci same nie kupowały biletu „w podróż do świata teatru” - nauczyciele robili to za nie; c) dzieci nie czytały przygotowanych przez nas programów, ani nie były ciekawe, dlaczego programy są w różnych kolorach.

2. Dzieci bardzo mocno przeżywały akcję przedstawienia.

3. Widzowie bardzo dobrze zrozumieli, że Młynek do kawy jest metaforą samotnego, odrzuconego człowieka.

4. Dzieci bardzo mocno utożsamiły się z bohaterem przedstawienia.

5. Odbiorców denerwowały powtórzenia w tekście przedstawienia i w działaniach aktorów.

6. Wiele osób nie rozumiało wszystkich użytych w przedstawieniu metafor. Wnioski:

1. Forma przedstawienia była dla odbiorów ciekawa, choć czasami drażniąca - uznaliśmy jednak, że niepokój czy nawet pewnego rodzaju rozdrażnienie mogły mieć pozytywny wpływ - pobudzały myślenie, zaś niedopowiedzenia dawały możliwość własnych interpretacji. W tym przypadku właśnie irytacja była siłą pobudzającą i aktywizującą odbiorcę.

2. Antyiluzyjna forma przedstawienia nie wpłynęła negatywnie na rozumienie jego wymowy, przeciwnie wydaje się, że właśnie dlatego odbiorca bardzo osobiście odebrał całe widowisko. 
3. Współczesne dzieci czują się odrzucone i marzą o miłości, co wyraźnie widać było w wypowiedziach zarówno ustnych jak i plastycznych. Śmierć Celiny nie była tak ważna jak powrót Młynka do domu.

3. Konik, 2006/2007 (działania adresowane do dzieci przedszkolnych w wieku 5-6 lat) - budowanie horyzontu skojarzeń ${ }^{4}$.

Założenia:

I etap eksperymentu przeprowadzony był $\mathrm{w}$ dwóch różnych formach, tzn. eksperyment realizowany był w dwóch przedszkolach w różny sposób:

1. Dzieci z pierwszego przedszkola trzykrotnie przychodziły do teatru, gdzie oglądały krótkie, trwające 2 minuty 10 sekund, przedstawienia, których bohaterem był duży drewniany koń. Zachowane zostały wszystkie elementy teatralnego zwyczaju - wprowadzanie na widownię, wygaszanie świateł, rozsunięcie kurtyny, działania sceniczne, zasunięcie kurtyny. Te spotkania z teatrem były niezwykle krótkie. Chodziło o działanie niekonwencjonalne, burzące stereotyp i tym samym zmuszające do stawiania sobie pytań. Element zaskoczenia, zdziwienia, a nawet pewnego rozczarowania czy irytacji miał na celu pobudzenie wyobraźni, uruchomienie myślenia. Dla tej grupy widzów spektakl miał zacząć się wraz z pierwszym spotkaniem teatralnym i trwać w wyobraźni aż do zakończenia właściwego widowiska, a więc około 10 dni.

2. Do drugiego przedszkola przychodzili aktorzy z 4 krótkimi, 5-minutowymi działaniami parateatralnymi. Tu także głównym bohaterem był koń.

II etap eksperymentu - przedstawienie oparte na konwencji cyrkowych pokazów różnych „numerów”. Tu wprowadzono na sceniczną arenę postaci zaczerpnięte z wielkiej literatury światowej (Don Kichot, Cyrano de Bergerac, Kandyd, Pierrot i Kolombina, Faust, Matka Courage, Dziewczynka z zapałkami, Stella z Młynka do kawy) oraz postaci z obrzędów ludowych (Niedźwiedź, Diabeł). Pomiędzy nimi pojawiała się postać Dziewczynki reprezentująca świat dziecka. Wszystko toczyło się wokół wielkiego konia, który w finale stawał się wehikułem marzeń.

III etap eksperymentu zawierał kilka elementów.

1. Aranżacja teatralnego foyer, której celem było przedłużenie spektaklu teatralnego w przestrzeń pozasceniczną, a nawet pozateatralną.

\footnotetext{
${ }^{4}$ Szczegółowe informacje na temat całego eksperymentu znaleźć można w artykule E. Tomaszewskiej Tworzenie horyzontu skojarzeń. Eksperyment teatralno-pedagogiczny „Konik” adresowany do dzieci młodszych, [w:] K. Krasoń, B. Mazepa-Domagała (red.), Oblicza sztuki dziecka. W poszukiwaniu istoty ekspresji, Katowice-Mysłowice 2007, s. 254-264.
} 
W szatni dzieci napotykały koniki na biegunach, a przy wyjściu z budynku stały koniki na patykach.

2. Przeprowadzenie zajęć plastycznych, w czasie których dzieci realizowały temat „Konik”.

Obserwacje:

1. Dla dzieci z pierwszego przedszkola krótkie przedstawienia teatralne były zaskakujące, wracając do przedszkola rozmawiały o nich.

2. Dzieciom z przedszkola drugiego podobały się krótkie scenki, ale niezwykle trudno było uruchomić ich wyobraźnię - nie pojawiły się improwizowane opowiadania o podróży w marzenia.

3. Dzieci z przedszkoli eksperymentalnych lepiej zrozumiały przedstawienie i jego wymowę.

4. Przedstawienie stało się dla dzieci impulsem do rozwijania własnych skojarzeń.

5. Dzieciom sprawiało radość odkrywanie w przedstawieniu znanych sobie postaci i sytuacji.

6. Dzieci chętnie podejmowały po spektaklu zabawę pozostawionymi konikami.

Wnioski:

1. Dzieci, które oglądały widowisko bez wcześniejszego przygotowania, odebrały je wrażeniowo, ale i dość powierzchownie.

2. W przypadku przedszkoli eksperymentalnych wcześniejsze wprowadzenie dzieci w temat wpłynęło na ukierunkowanie asocjacji i związanie ich z wymową przedstawienia.

3. Spektakl otworzył wyobraźnię dzieci na różne skojarzenia, niekoniecznie związane z samym przedstawieniem. Wynikało to, być może, z samej formuły teatralnej o konstrukcji otwartej, która pozwalała na łączenie różnych form, postaci, myśli w ramach jednej struktury teatralnej.

We wszystkich powyżej opisanych działaniach teatralnych przedstawienie pobudziło dzieci do przemyślenia wielu spraw, najczęściej jednak związanych z ich własnym życiem. Dokonywały porównań akcji scenicznej, sytuacji teatralnej ze zdarzeniami z własnego życia, a wiele z nich wykorzystywało akcję sceniczną do dygresji odnoszących się do ich własnych doświadczeń5

\footnotetext{
${ }^{5}$ Oto przykładowe wypowiedzi dzieci biorących udział w eksperymentach: „Chodzę nad staw i patrzę na kaczki, a wcześniej nie chodziłem, bo nie było na co patrzeć”; „Na bajce było wesoło, a w moim domu smutno” (Kaczka i Hamlet); „Bo widzi Pani, są ludzie co biorą psa, bo dziecko ma taką zachciankę, a potem to im się nudzi i go wyrzucają. Albo adoptują dzieci, a potem przybrani
} 


\section{Działania teatralne wychodzące z założeń tzw. teatru wyobraźni}

Efekty zaprezentowanych eksperymentów oraz doświadczenie, jakie zdobyliśmy w czasie ich realizacji, zmobilizowały nas do kontynuowania badań. Tym razem sięgnęliśmy do innej formuły, którą nazwaliśmy teatrem wyobraźni.

W 1934 roku Stanisław Naszydłowski zaproponował „teatr wyobraźni”, czyli słuchowisko grane „na żywo”, jako interesującą alternatywę dla przedstawienia teatru szkolnego. W „Przyjacielu Szkoły” pisał:

Pierwsze przedstawienie wyobraźni odbyło się w Wejherowie w roku 1933 z racji uroczystości 70-lecia powstania styczniowego. Na program złożyły się: odczyt, deklamacje, chór, a na zakończenie odegrano „Echa leśne” Żeromskiego. Rzecz nietrudna do przerobienia na słuchowisko. Aktorzy grają za spuszczoną kurtyną. Do słuchaczy dochodzą głosy rozmów, odbierają też wrażenia akustyczne, które w wyobraźni słuchacza tworzą wrażenia np. przejazdu konnicy, bitwy, szumu boru itp. [...] Zachęceni udanym przedstawieniem „Ech leśnych” uczniowie na obchód 11 listopada odegrali „Przyjazd J. Piłsudskiego do Warszawy". Tu technika podania wrażeń akustycznych miała bogate pole do popisu i pomysłowości ${ }^{6}$.

Tego typu przedstawienia nie były odosobnione, a nawet zalecano je jako jedną z form aktywności artystycznej dzieci. Należy jednak podkreślić, że miała to być zastępcza forma teatru realizowana w sytuacji braku odpowiednich środków na przygotowanie kostiumów czy dekoracji.

Często jednak brak kostiumów względnie wysokie koszta ich sprowadzenia lub nadmierna praca przy ich sporządzaniu zniechęca nauczycieli do wystawiania sztuk i nieraz jest powodem zaniechania urządzenia uroczystości. [...] Te kłopoty nasunęly mi myśl wprowadzenia do szkoły „teatru wyobraźni”, wzorowanego na słuchowiskach radiowych. [...] Naturalnie, że nie zastąpi „teatr wyobraźni” - „teatru prawdziwego", lecz jest niewątpliwie lepszy niż przedstawienia o wątpliwej wartości dekoracyjnej i kostiumowej, a często nawet wręcz fałszywej ${ }^{8}$.

Takie podejście łączy się z koncepcją teatru szkolnego traktowanego jako naśladownictwo teatru zawodowego. Formuła ta, niezwykle popularna w okresie międzywojennym, a także po II wojnie światowej, stanowiła i chyba nadal stanowi fundament działań amatorskich grup teatralnych.

rodzice go nie chcą, a ono to czuje i jest jak ten Młynek” (Młynek do kawy); „Najbardziej podobał mi się żołnierz ze złamaną ręką, bo mój tatuś jest policjantem" (Konik).

${ }^{6}$ S. Naszydłowski, Teatr wyobraźni w szkole, „Przyjaciel Szkoły” 1934, nr 3.

${ }^{7}$ Por.: I. Michalska, $Z$ tradycji polskich teatrów szkolnych, [w:] M. Zalewska-Pawlak (red.), Sztuka wobec zakresów wolności człowieka liberalnego, Łódź 2009, s. 293-295.

${ }^{8}$ Ibidem. 
Warto jednak dodać, że równolegle istniała koncepcja „teatru samorodnego"9 , która stawiała nie na naśladownictwo, a na ekspresję własną dzieci i młodzieży.

Do takiego sposobu myślenia o teatrze dziecięcym nawiązał Jan Do$\operatorname{rman}^{10}$, który po wojnie podjął działania zmierzające do stworzenia międzyszkolnego teatru dzieci i młodzieży na terenie Sosnowca. Zwrócił on uwagę, że proponowana w okresie międzywojennym forma „słuchowiska na żywo" znacząco aktywizuje wyobraźnię dzieci, zarówno tych tworzących przedstawienie dźwiękowe, jak i słuchaczy. Postanowił połączyć elementy słuchowiska i przedstawienia teatralnego. W $1946 \mathrm{roku}$, na zorganizowanym przez siebie kursie teatralnym dla kierowników teatrów szkolnych, wprowadził słuchowisko jako inspirację do twórczości teatralnej dzieci:

W wyznaczonym dniu zebraliśmy zaproszone dzieci „kolonijne” na łąkę, gdzie zwykle bawiły się ze sobą. Na łące stał płot. Jedna grupa usadowiła się z jednej, a druga $z$ drugiej strony płotu. [...] Słuchowisko. Reakcja dzieci po odbiorze różna [...] I wtedy wystąpił kursista wyznaczony wcześniej do tej roli (była to Wanda, ta kusząca dobrze i wściekle profesora Szumana) i zaproponował dzieciom zabawę. Niechaj dzieci zabawią się w teatr. Niechaj spróbują zagrać to, co usłyszały. [...] Obydwie grupy, ta za płotem i ta przed płotem przystąpiły do działania. Najpierw rozmowa: kto, co, jak. Mamy płot. No to będzie parawan. Więc zagramy lalkami. Ale lalki? Dzieci rozglądają się. Czym dysponują. Są gałązki i trawa i gazety rzucone, zżółkłe, wyczytane. Biegają po łące. Szukają. Jedne przed drugimi ${ }^{11}$.

Potem kontynuował te doświadczenia w codziennej pracy z dziećmi w ramach Eksperymentalnego Teatru Dziecka, jaki prowadził w latach 1946-1949 w Sosnowcu. Pracę teatralną rozpoczynał od czytania dzieciom bajek, historyjek, opowiastek, które potem poprzez zabawę dzieci samodzielnie przekładały na język teatru („Dzieci codziennie przychodziły bawić się w teatr. Czytane były bajki, a następnie dzieci bawiły się w te bajki, inscenizowały je"12).

Niemal od początku swojej pracy Dorman utrzymywał kontakty z rozgłośnią Polskiego Radia w Katowicach, realizując z dziećmi słuchowiska - Malowane dzbanki (1946), Bałwan chwat idzie w świat (1948). Niemożliwe jest dziś odtworzenie kształtu tych audycji i słuchowisk, gdyż nagrania

\footnotetext{
${ }^{9}$ Nazwę „teatr samorodny” wprowadzili Wacław Budzyński i Zdzisław Kwieciński, zwracając uwagę na wydobycie z młodego aktora tego, co już w nim jest, jego własnej ekspresji twórczej, nie narzucając konwencji zapożyczonych z profesjonalnego teatru. Wybitnym realizatorem tej formuły był Lucjusz Komarnicki.

${ }^{10}$ Jan Dorman (1912-1986), pedagog, wybitny twórca teatralny, założyciel „Teatru Dzieci Zagłębia” w Będzinie.

${ }^{11}$ E. Tomaszewska, Jan Dorman, poeta teatru, Katowice 2010, s. 84.

${ }^{12}$ Ibidem, s. 94.
} 
z tamtych lat bądź zaginęły, bądź zostały zniszczone. Wiadomo jednak, że Dorman każdą audycję poprzedzał słowem wstępnym. W jego notatkach odnalazł się brudnopis jednej z takich pogadanek:

Radio absorbując zmysł słuchu, poprzez który buduje obrazy wrażeniowe, musi szukać pomocy elementów bardziej bezpośrednio wpływających. Nasz kontakt z Radiem polega właśnie na uzupełnieniu braków wrażeniowych. Współpracę oparliśmy na metodzie równoległej pracy. Radio buduje słuchowisko - my powtarzamy go na scenie. Montowanie słuchowiska jest równocześnie komponowaniem szkieletu widowiska. Dzieci słuchają bajki, a później się bawią. Dzieci znając treść, budulec zabawy łatwiej ją tworzą. Obrazy powstałe w wyobraźni urzeczywistniają się, realizują na scenie. Piosenka usłyszana w radiu przechodzi do bawiących się dzieci. Bawią się, śpiewają, przenoszą zabawę na podwórko, na ulicę... Wyniki naszej pracy są pozytywne. Słuchowiska odbywają się co miesiąc. Obok wspomnianej metody ich wykorzystania, służą do ogłaszania konkursów, a zatem wykorzystujemy je podwójnie. Obecnie mamy za sobą pięć miesięcy współpracy ${ }^{13}$.

Wykorzystanie słuchowiska $\mathrm{w}$ pracy z dziećmi może mieć zatem różne formy: być ekspresją własną dzieci tworzącą wyimaginowane rzeczywistości bez dekoracji i kostiumów lub inspirować działania teatralne. Wydaje się, że właśnie dopełnianie się różnych form artystycznych oddziaływań staje się istotną wartością przytoczonych propozycji pracy z dziećmi ${ }^{14}$. To właśnie nasunęło nam pomysł zrealizowania nowego typu działań teatralnych, których istotą byłaby interaktywność oraz wykorzystanie wielu tworzyw do aktywizacji dzieci, uczestników zdarzenia artystycznego, a wyobraźnia byłaby jedną z przestrzeni kreacji.

Pierwszym takim działaniem była realizacja dwóch sztuk Jana Wilkowskiego o przygodach małego misia Tymoteusza ${ }^{15}$ : Tymoteusz wśród ptaków (Wiosenna przygoda Tymoteusza) oraz Tymoteusz Rymcimci. Pierwszy tekst przedstawiony został dzieciom jako słuchowisko grane na żywo. Po wysłuchaniu słuchowiska dzieci rysowały bohaterów zasłyszanej opowieści ${ }^{16}$.

${ }^{13}$ J. Dorman, Wspólpraca Radia z Teatrem Dziecka, pogadanka, rękopis z 1946, Archiwum Jana Dormana w Będzinie.

${ }^{14}$ Naszydłowski wspomina także, że: „... wolę już dzieci zaprowadzić na przedstawienie «teatru wyobraźni», zapoznając je uprzednio, jeśli tego zachodzi potrzeba, z odpowiednimi ilustracjami, które dadzą możliwość wyobrażenia sobie strojów względnie umundurowań osób, które w sztuce mają wystąpić". 2012.

${ }^{15}$ Eksperyment ten realizowaliśmy kilkakrotnie: maj 2008, listopad 2009, listopad 2011 - maj

${ }^{16}$ Szerszy opis tych działań znaleźć można w: E. Tomaszewska, Teatr wyobraźni, [w:] K. Krasoń, B. Mazepa-Domagała, A. Wąsiński (red.), Intersubiektywność sztuki w recepcji i tworzeniu, Bielsko-Biała-Katowice 2009, s. 167-177. 
Drugim etapem było przygotowanie przedstawienia teatralnego opartego na drugim tekście Wilkowskiego, opowiadającym inną przygodę tych samych bohaterów. Ponieważ dzieci już wcześniej wyobraziły sobie wszystkie postaci, mogliśmy wprowadzić na scenę formy bardzo umowne, niemal abstrakcyjne, które tylko symbolizowały bohaterów opowieści i miały pełnić funkcję „ekranów” przyjmujących na siebie wyobrażenia dzieci.

Początkowo realizowaliśmy te działania w przedszkolach, ale później podjęliśmy także próbę przygotowania przedstawienia w sali teatralnej, gdzie spektakl składał się z dwóch aktów - pierwszym było słuchowisko wsparte całkowicie abstrakcyjną wizualizacją komputerową, drugim było przedstawienie, w którym wykorzystano formy plastyczne. I tym razem jednak w przerwie między pierwszym i drugim aktem dzieci rysowały (wizualizowały) swoje wyobrażenia postaci.

Dzieci doskonale odebrały całość zaproponowanej przez nas zabawy teatralnej i z wielkim entuzjazmem brały w niej udział. Zadaliśmy więc sobie pytanie, czy podobna formuła sprawdzi się wobec widowni starszej. Zwróciliśmy się z propozycją współpracy do Liceum Ogólnokształcącego w Cieszynie. Jako literacką bazę wzięliśmy tekst Jeana Giraudoux Wariatka $z$ Chaillot. Akt I zaprezentowany został jako słuchowisko; akt II zagrany był jako spektakl teatralny z wykorzystaniem form plastycznych stanowiących znaki postaci, które występowały w części słuchowiskowej ${ }^{17}$. Jednocześnie oba te elementy potraktowane zostały jako kolejne dwa etapy artystycznego oddziaływania rozdzielone interwałem czasowym (3 tygodnie). Chodziło o to, aby temat przedstawiony w części pierwszej „uleżał się” w pamięci młodzieży, żeby miała ona czas na przemyślenie go. Odwołaliśmy się do nieświadomie porządkującej aktywności ludzkiego mózgu, w czasie której nagromadzone w toku różnych działań czy doświadczeń informacje są analizowane i przetwarzane w umyśle poza świadomością człowieka ${ }^{18}$. Chodziło właśnie o to, aby w przerwie między jedną częścią naszego artystycznego eksperymentu a drugą nastąpił okres inkubacji, ustosunkowania się do przedstawionej opowieści. Sama młodzież komentowała pomysł w ten sposób: „Uważam, że pomysł przedstawienia sztuki w dwóch etapach jest bardzo ciekawy. Pozwala widzowi na lepszy odbiór inscenizacji, głębsze zapoznanie się z ideą sztuki”.

\footnotetext{
${ }^{17}$ Scenariusz oparty na wydaniu: Jean Giraudoux, Teatr, Warszawa 1957.

${ }^{18}$ Por. też Gestalt, psychologia postaci.
} 
Główny sens dwuczęściowej inscenizacji polegał na tym, że odbiorca zapoznawszy się z częścią pierwszą, miał czas w codziennym życiu na jej interpretację i analizę. Dzięki temu, oglądając drugą część, nie czuł się bierny wobec tej tematyki.

Po całym eksperymencie uczniowie napisali recenzje, które stały się podstawą badań recepcji tego przedsięwzięcia w pracy licencjackiej pani Małgorzaty Hanulok ${ }^{19}$.

Słuchowisko odegrane zostało w szkole, w ramach lekcji języka polskiego. Trwało ok. 20 minut, a jednak młodzież z dużym zainteresowaniem słuchała i nie wykazywała oznak nudy, choć nie było to dla odbiorców doświadczenie łatwe. Jedna z osób napisała:

Słuchowisko było dobrze zrealizowane, jednak w tych nieszczęsnych czasach trudno młodemu człowiekowi (zaledwie siedemnastoletniemu) w pełni skupić się i przez całe 45 minut siedzieć grzecznie i słuchać. Jako dziecko kultury wizualnej, niejednokrotnie tandetnej, nie posiadam umiejętności operowania wyobraźnią i wczuwania się w rzeczywistość, która jest mi właściwie nieznana ${ }^{20}$.

Mimo to młodzież podkreśliła, że to ciekawa i pobudzająca forma komunikacji artystycznej, także mobilizująca do sięgnięcia po tekst: „już w pierwszym etapie sztuki dołączyłam ten tytuł do listy tytułów, które w przyszłości chciałabym przeczytać" ${ }^{21}$. Ostatecznie ponad 3/4 odbiorców oceniło pozytywnie nasz pomysł i stwierdziło, że słuchowisko oddziałało mocno na ich wyobraźnię.

Spektakl, podobnie jak słuchowisko, odegrany został w przestrzeniach liceum: w klasie, w szkolnym sklepiku, na korytarzu, na schodach do piwnicy i wreszcie w szatni, gdzie widowisko kończyło się. Widzowie wkomponowani byli w akcję sceniczną i stanowili zarówno element scenografii, jak i samej akcji. W ten sposób próbowaliśmy przełamać podział na scenę i widownię, nawiązując $\mathrm{z}$ jednej strony do doświadczeń happeningu, $\mathrm{z}$ drugiej - do rytuału ${ }^{22}$. Okazało się, że to artystyczne rozwiązanie było bardzo trafione.

\footnotetext{
${ }^{19}$ M. Hanulok, Rola teatru w pobudzaniu wyobraźni dzieci i młodzieży, niepubl. praca licencjacka napisana pod kier. dr Ewy Tomaszewskiej, UŚ, WEiNoE w Cieszynie, specjalność ASK, Cieszyn 2011.

${ }^{20} \mathrm{Na}$ podstawie recenzji, jakie napisała młodzież po zakończeniu całego projektu. Opracowaniem tego materiału zajęła się Małgorzta Hanulok, ibidem, s. 56.

${ }^{21}$ Ibidem.

${ }^{22}$ Warto tu nawiązać do idei „święta” oraz „kultury czynnej” wprowadzonej w miejsce tradycyjnego teatru przez Jerzego Grotowskiego. Te idee znalazły wielu kontynuatorów i składają się dziś na dość silny nurt parateatrów, teatrów alternatywnych czy ogólnie mówiąc teatru antropologicznego (Na drodze do kultury czynnej. O działalności instytutu Grotowskiego Teatr Laboratorium w latach
} 
16 osób [na 26 uczestniczących w eksperymencie - przyp. E. T.] wskazało, że przedstawiona forma realizacji teatralnej jest interesująca dla młodego odbiorcy, 1 osoba temu zaprzeczyła, 1 napisała, iż trudno to ocenić, a 8 osób nie ustosunkowało się do postawionego pytania. Do plusów przedsięwzięcia 8 uczniów zaliczyło oryginalny i innowacyjny pomysł, nie spotykany dotąd. 3 osoby otwarcie przyznały w swojej recenzji, że forma ta na długo utkwi im w pamięci. 13 osób przyznało, że aktywne uczestniczenie w przedstawieniu, było ciekawym pomysłem i dzięki temu sztuka wydała im się bardziej realna i wciągnęła ich w wir akcji, która była zawrotna i dynamiczna - nie było monotonii, cały czas coś się działo. W dodatku sztuka przekazywała ważne treści, nie zanudzając przy tym widza ${ }^{23}$.

Należy jednak dodać, że nie wszystkie nasze założenia udało się zrealizować, a granie spektaklu w przestrzeni szkoły przyniosło nieprzewidziane okoliczności, które bardzo utrudniły odbiór sztuki. Mimo to młodzież zrozumiała przesłanie, wciągnęła się w akcję i odnalazła uniwersalne treści dzięki własnym przemyśleniom. Nasza idea przedstawienia mobilizującego młodych odbiorców sztuki do aktywnego uczestnictwa w przedstawieniu, a także idea pozostawiania w pamięci śladów, które w przyszłości mogą zostać wypełnione głębszą treścią - sprawdziła się. Mimo wielu niedoskonałości realizacyjnych i trudności młodzież chciała obejrzeć to widowisko jeszcze raz. Poruszona przez nas tematyka, a także nowatorska forma ${ }^{24}$ teatralna obudziły ciekawość, a także chęć wypowiedzi - nauczycielka, z którą współpracowaliśmy przy organizacji tego przedsięwzięcia napisała po przedstawieniu maila z informacją: „Młodzież domaga się pisania recenzji”. To dość rzadki w praktyce szkolnej przypadek, w którym uczniowie chcieli podzielić się swoimi spostrzeżeniami, przeżyciami, przemyśleniami. Jedna z osób napisała: „Szuka zmuszała do chwili zastanowienia i nasuwają mi się coraz to nowe przemyślenia”. Okazuje się zatem, że nasze wstępne założenia dotyczące pobudzenia odbiorcy do własnych refleksji i uruchomienia jego wyobraźni udało się zrealizować.

Badania potwierdziły zasadność działań artystycznych i niezwykle pozytywny wpływ sztuki, zarówno w formie ekspresji własnej jak i w formie recepcji, na indywidualny rozwój młodych ludzi. W naszych propozycjach

1970-1977, oprac. i dokumentacja prasowa L. Kolankiewicz, Wrocław 1978; T. Kornaś, Parateatr, „Didaskalia. Gazeta Teatralna”, cz. I: 2002, nr 51/52, s. 49-55; cz. II: 2003, nr 53, s. 98-102; cz. III: 2003, nr 54-56, s. 77-84.

${ }^{23}$ M. Hanulok, Rola teatru w pobudzaniu..., s. 55.

${ }^{24}$ Forma teatralna, którą zaproponowaliśmy, wcale nie jest nowatorska; tego typu przedstawienia realizowane są w alternatywnych teatrach od lat sześćdziesiątych XX w. To młodzież ma niewielką wiedzę i doświadczenia teatralne, ale temat ten jest zbyt obszerny, aby omawiać go w ramach tego rozdziału. 
wprowadziliśmy elementy łączące obie te sfery - dzieci były odbiorcami, ale jednocześnie pozostawiono przestrzeń dla ich własnej kreacji, którą włączono do działań scenicznych. Spełniało to funkcję aktywizacji widza, która została potwierdzona. Spotkania z teatrem mogą być więc formą przeciwdziałania społecznemu otępieniu wynikającemu z permanentnych oddziaływań mediów, coraz częściej przybierających formy manipulacji.

W trakcie pracy zauważono, że realizacja teatralna stała się także dla twórców niezwykle inspirująca, rozwijająca i pobudzająca do myślenia. I nie chodzi tu tylko o sprawy artystyczne, ale także o rozwój zawodowy przyszłych animatorów kultury i ich rozwój indywidualny, osobowościowy. Studenci animacji nie tylko w sposób praktyczny zweryfikowali pewne teorie, z którymi zetknęli się w trakcie studiów. Odkryli także samych siebie w twórczym działaniu, które dało im wiele satysfakcji i wiary we własne możliwości, a także przekonanie o znaczeniu i wadze pracy, którą podjęli. Zobaczyli bowiem, że adresaci tych działan - czy to dzieci, czy młodzież - czerpią z tych propozycji wiele dobrego, zostają zmobilizowani do aktywności, która okazuje się dla nich ważna i pobudza zarówno wyobraźnię jak i intelekt. Potwierdzają to wypowiedzi studentów:

Zajęcia $\mathrm{w}$ takiej formie nauczyły mnie jak pracować z grupą przygotowując przedstawienie. Nigdy wcześniej nie miałam do czynienia z takiego typu praktyką. Teraz mniej więcej wiem, ile czasu zajmują przygotowania, na co trzeba zwrócić szczególną uwagę.

Uświadomiłam sobie jak wielką rolę w rozwoju dziecka ma teatr i jego pochodne. Sądzę, że po takim doświadczeniu będę angażować się lub też inicjować podobne eksperymenty. Jestem pod ogromnym wrażeniem tego, czego jako grupa dokonaliśmy. Myślę, że my również zyskaliśmy i nauczyliśmy się wiele o sobie. Przede wszystkim, mam nadzieję, że zrobiliśmy wielką przysługę dzieciom, pokazaliśmy im inny, piękniejszy świat i sprowokowaliśmy ich wyobraźnię. Jestem pewna, że ich dusze zostały poruszone i niebawem będą latać.

Nauczyłam się, że trzeba wierzyć w ludzi i starać się im zaufać. Wszelkie odstępstwa od normy, niezwyczajność tego spektaklu więcej dają człowiekowi niż ciągle powielane schematy. Uświadomiłam sobie, że teatr żyje w pełnym tego słowa znaczeniu, a tworzenie daje radośćc 5 .

Teatr zawsze cechuje powstawanie przestrzeni „pomiędzy” sceną a widownią. Twórcy przygotowują przedstawienie, które jest oparte na całym systemie znaków. Widzowie te znaki muszą odczytać i wypełnić własną tre-

${ }^{25}$ Ewa Tomaszewska, „Scena Szkolna” UŚ w Cieszynie - funkcje warsztatów teatralnych w nauczaniu studentów ASK, [w:] K. Olbrycht, E. Konieczna, J. Skutnik (red.), Upowszechnianie kultury - wyzwaniem dla edukacji kulturalnej, Toruń 2008, s. 315-317. 
ścią (interpretacja). W naszym przypadku poszliśmy dalej. Owa przestrzeń „pomiędzy” była eksplorowana przez obie strony i stała się przestrzenią autentycznego spotkania, które wpłynęło na obie strony tej artystycznej „rozmowy”. W ten sposób powstała przestrzeń stała się także platformą przenikania wpływów, inspiracji i bodźców pobudzających twórcze myślenie. Właśnie aby podkreślić ten aspekt, użyliśmy określenia „interaktywny”. Wskazuje ono i podkreśla wielokierunkowość oddziaływań sztuki teatru, które traktuje się jako cechę podstawową.

Dla animatora to bardzo ważne i znaczące. Józef Kargul ${ }^{26}$ uważa, że animacja to działanie wśród ludzi i z ludźmi, które ma na celu ułatwienie jednostce oraz grupie udziału w bardziej aktywnym i twórczym życiu przez lepsze rozumienie przemian, łatwiejsze porozumiewanie się i współudział $\mathrm{z}$ innymi w ożywianiu środowiska. Jest także animacja metodą działania i jawi się jako stymulacja jednostek i grup, a także społeczności lokalnych do twórczego działania mającego na celu ulepszenie życia społecznego środowiska przez ukazanie wizji owych ulepszeń i stymulowanie ludzi do ich realizacji. Wszystkie uczestniczące w tym procesie jednostki są na równych prawach i zasadach, a szczególną rolę odgrywa tu empatyczny charakter animatora. Dzięki temu możliwe jest odkrywanie wewnętrznych sił twórczych i pobudzanie do zachowań ekspresyjnych. Tak rozumiana animacja jest więc także procesem poznawania samego siebie. W ten sposób następuje odkrywanie w sobie możliwości kreacyjnych, sił twórczych. Proces animacji w tym znaczeniu ułatwia odnalezienie własnego „ja” i dostrzeżenie w sobie potencjału drzemiącego w każdym człowieku.

Łatwo dostrzec podobieństwa między teorią animacji i proponowanymi przez nas działaniami teatralnymi. Efekty przedstawionych powyżej procesów artystycznych oraz animacyjnych są podobne. Sztuka powinna zatem być jedną z ważniejszych dróg, którymi podążać ma współczesny animator, a teatr może pełnić tu rolę szczególnie znaczącą.

\section{Bibliografia}

Dorman J., Współpraca Radia z Teatrem Dziecka, pogadanka, rękopis z 1946, Archiwum Jana Dormana w Będzinie.

Dorman J., Zabawa dzieci w teatr, Warszawa 1981.

\footnotetext{
${ }^{26}$ [Za:] T. Pilch, I. Lapczyk (red.), Pedagogika społeczna, Warszawa 1997, s. 273.
} 
Hanulok M., Rola teatru w pobudzaniu wyobraźni dzieci i młodzieży, niepubl. praca licencjacka, UŚ, WEiNoE w Cieszynie, kierunek ASK, promotor: dr E. Tomaszewska, Cieszyn 2011.

Kargul J., Animacja społeczno-kulturalna, [w:] T. Pilch, I. Lapczyk (red.), Pedagogika społeczna, Warszawa 1997.

Michalska I., Z tradycji polskich teatrów szkolnych, [w:] M. Zalewska-Pawlak (red.), Sztuka wobec zakresów wolności człowieka liberalnego, Łódź 2009.

Naszydłowski S., Teatr wyobraźni w szkole, „Przyjaciel Szkoły” 1934, nr 3.

Nowicka M., Ile nas łączy, ile nas dzieli, „Wiedza i Życie” 2012, nr 8(932).

Tomaszewska E., Jan Dorman, poeta teatru, Katowice 2010.

Tomaszewska E., Kaczka i Hamlet. Eksperyment teatralno-pedagogiczny, [w:] M. Knapik, W. A. Sacher (red.), Sztuka w edukacji i terapii, Kraków 2004.

Tomaszewska E., Kaczka i Hamlet. Kilka uwag z eksperymentu, [w:] K. Krasoń, B. Mazepa-Domagała (red.), Ekspresja twórcza dziecka, Katowice 2004.

Tomaszewska E., Młynek do kawy, czyli teatr dla dzieci starszych, [w:] K. Krasoń, B. Mazepa-Domagała (red.), W kręgu sztuki i ekspresji dziecka. Rozważania inspirujace, Mysłowice 2006.

Tomaszewska E., „Scena Szkolna” UŚ w Cieszynie - funkcje warsztatów teatralnych w nauczaniu studentów ASK, [w:] K. Olbrycht, E. Konieczna, J. Skutnik (red.), Upowszechnianie kultury - wyzwaniem dla edukacji kulturalnej, Toruń 2008.

Tomaszewska E., Teatr wyobraźni, [w:] K. Krasoń, B. Mazepa-Domagała, A.Wąsiński (red.), Intersubiektywność sztuki w recepcji i tworzeniu, Bielsko-Biała-Katowice 2009.

Tomaszewska E., Tworzenie horyzontu skojarzeń. Eksperyment teatralno-pedagogiczny „Konik" adresowany do dzieci młodszych, [w:] K. Krasoń, B. Mazepa-Domagała (red.), Oblicza sztuki dziecka. W poszukiwaniu istoty ekspresji, Katowice-Mysłowice 2007.

Wolne miejsce dla wyobraźni, wywiad z Krystyną Miłobędzką przeprowadzony przez Ewę Tomaszewską, „Filia” 1995/1996, nr 25, s. 7-9. 